\title{
Dietary addition of curcumin favors weight gain and has antioxidant, anti-inflammatory and anticoccidial action in dairy calves
}

\author{
La adición de curcumina en la dieta de los terneros lecheros favorece el aumento de peso y tiene acción \\ antioxidante, antiinflamatoria y anticoccidial \\ A adição de curcumina na dieta dos bezerros leiteiros favorece o aumento de peso e tem ação \\ antioxidante, anti-inflamatória e anticoccidiostática
}

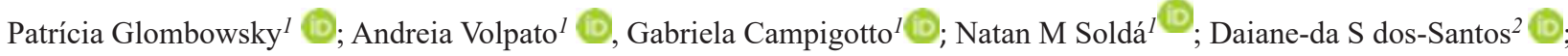

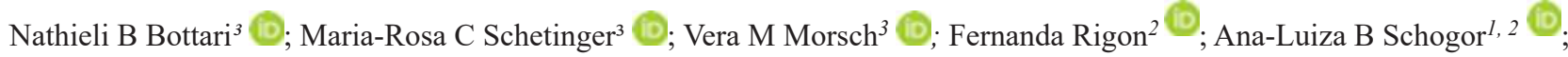
Aleksandro S Da-Silva ${ }^{1,2,3 *}$.

${ }^{1}$ Programa de Pós-graduação em Zootecnia, Universidade do Estado de Santa Catarina (UDESC), Chapecó, Santa Catarina (SC), Brasil. ${ }^{2}$ Departamento de Zootecnia, Universidade do Estado de Santa Catarina (UDESC), Chapecó, Santa Catarina (SC), Brasil.

${ }^{3}$ Departamento de Bioquímica e Biologia Molecular, Universidade Federal de Santa Maria (UFSM), Santa Maria, Rio Grande do Sul (RS), Brasil.
\end{abstract}

Received: February 28, 2018; accepted: August 9, 2019

To cite this article:

Glombowsky P, Volpato A, Campigotto G, Soldá NM, dos-Santos DdS, Bottari NB, Schetinger MRC, Morsch VM, Rigon F, Schogor ALB, Da-Silva AS. Dietary addition of curcumin favors weight gain and has antioxidant, anti-inflammatory and anticoccidial action in dairy calves. Rev Colomb Cienc Pecu 2020; 33(1): 16-31

DOI: https://doi.org/10.17533/udea.rccp.v33n1a02

\section{(cc) $\mathrm{BY}-\mathrm{NC}-\mathrm{SA}$}

*Corresponding author: Rua Beloni Trombeta Zanin, 680E, Bairro Santo Antônio, Chapecó, SC, Brasil. 89815-630. Tel.: +55 49 2049-9560. E-mail: aleksandro_ss@yahoo.com.br 


\section{Abstract}

Background: Curcumin has been used as an additive in the diet of animals in recent years due to the potent medicinal properties of this molecule. Objective: To evaluate whether the addition of curcumin to the diet of calves at different phases (pre- and post-weaning) has a positive effect on metabolic profile, performance, and anti-coccidian action. Methods: Thirtythree Holstein calves were selected at various phases of development: Experiment 1 (E1:n=10) 18 7 (pre-weaning), Experiment 2 (E2: n=11) $64 \pm 4$ (pre-weaning) and Experiment 3 (E3: n=12) 95 \pm 8 (post-weaning) days of life. The calves were separated in three groups according to their phase of development. In each experiment, animals were divided into two sub-groups: control and curcumin. The curcumin groups received $200 \mathrm{mg}$ of additive per animal/day either in milk (pre-weaning) or concentrate (post-weaning). Fecal collections were performed on days 0,10 and 15 of the experiment to count Eimeria oocysts per gram of feces and to perform fecal score analysis. Complete blood counts, oxidant and antioxidant profiles, protein metabolism markers, lipid levels, glucose levels, and animal weights were measured. Analyses of digestibility and composition of the diet used in Experiment 3 (post-weaning) were also performed. Results: Independent of phase, animals that received curcumin had greater weight gain on days 0 to 15 (E1, E2 and E3 p=0.04, 0.001 and 0.001 , respectively), probably due to the increased digestibility of hay and concentrate at $72 \mathrm{~h}(\mathrm{p}=0.03$ and 0.02 , respectively). The supplemented calves had lower level of oxidants (thiobarbituric acid reactive substances -TBARS- and reactive oxygen species -ROS-), indicating that free radical levels in serum and lipid peroxidation were lower. This was probably due to increased enzymatic antioxidants gluthatione S-transferase (E1, E2 and $\mathrm{E} 3 \mathrm{p}=0.001,0.001$ and 0.02 , respectively), catalase $(\mathrm{E} 1 \mathrm{p}=0.001)$ and superoxide dismutase ( $\mathrm{E} 3 \mathrm{p}=0.001)$ in treated animals at day 15. Furthermore, calves receiving curcumin had lower numeric number of Eimeria infection during the experimental period, and the difference was significant in day 15 (E1 and E2 p=0.02, and 0.001, respectively). Conclusion: Curcumin supplementation to dairy calves has coccidiostatic potential, favoring weight gain.

Keywords: animal stress; antioxidants; calves; cattle growth; curcumin; Eimeria; parasitology; supplementation.

\section{Resumen}

Antecedentes: Curcumina ha sido utilizada como aditivo en la dieta de animales en los últimos años, debido a las potentes propiedades medicinales de esa molécula. Objetivo: Evaluar si la adición de curcumina en la alimentación de terneras en diferentes fases (pre y post-destete) presenta efecto positivo sobre el perfil metabólico, desempeño de los animales, y acción anti-coccidial. Métodos: Se seleccionaron 33 terneros Holstein en varias etapas de desarrollo: Experimento 1 (E1: n=10) $18 \pm 7$ (pre-destete), Experimento 2 (E2: n=11) 64 \pm 4 (pre-destete) y Experimento 3 (E3: n=12) 95 \pm 8 (post-destete) días de vida. Para todos los experimentos, el período experimental fue de 15 días. Los animales se dividieron en dos grupos: control y tratados con curcumina. Los grupos con curcumina recibieron una dosis de $200 \mathrm{mg}$ del aditivo por animal/día en la leche (pre-destete) o en el concentrado (post-destete). Las colectas de heces y sangre fueron realizadas en los días 0,10 y 15 para conteo de ooquistes de Eimeria por gramo de heces y análisis de puntaje fecal. Se realizó hemograma, perfil oxidante y antioxidante, metabolismo proteico, lipídico, glucosa sanguínea y pesaje de los animales. También se realizó análisis de digestibilidad de la dieta total para los animales del Experimento 3 (post-destete). Resultados: Encontramos que, independientemente de la fase, los animales que recibieron curcumina tuvieron una mayor ganancia de peso en los días 0 a 15 (E1, E2 y E3, p=0,04, 0,001 y 0,001, respectivamente), probablemente debido al aumento de la digestibilidad del heno y concentrado a las $72 \mathrm{~h}$ ( $\mathrm{p}=0,03$ y 0,02 , respectivamente). En los terneros suplementados observamos un nivel más bajo de oxidantes (oxidantes (sustancias reactivas al ácido tiobarbitúrico y especies reactivas de oxígeno); es decir, los niveles séricos de radicales libres y la peroxidación lipídica fueron más bajos. Esto se debió, probablemente, a los antioxidantes enzimáticos glutatión S-transferasa (E1, E2 y E3 p =0,001, 0,001 y 0,02 respectivamente), catalasa $(E 1, p=0,001)$ y superóxido dismutasa $(E 3, p=0,001)$ que aumentaron en los animales tratados al día 15. Además, los terneros que recibieron curcumina tuvieron niveles más bajos de infección por Eimeria durante el período experimental y fueron significativos en el día 15 (E1 y E2, p=0,02 y 0,001, respectivamente). Conclusión: La suplementación con curcumina tiene potencial coccidiostático y favorece la ganancia de peso en terneros Holstein.

Palabras clave: antioxidantes; crecimiento de ganado; curcuminatiene; Eimeria; estrés animal; parasitología; suplementación; terneros.

\section{Resumo}

Antecedentes: Curcumina tem sido usado como aditivo na dieta de animais nos últimos anos, devido as propriedades medicinais potente dessa molécula. Objetivo: Avaliar se a adição de curcumina na alimentação de bezerras em diferentes fases (pré e pós-desmame) apresenta efeito positivo sobre perfil metabólico, desempenho e ação anti-coccidéo. Métodos: Para isso, 
33 bezerros holandeses foram selecionados em vários estágios de desenvolvimento: Experimento 1 (E1: $\mathrm{n}=10)$ 18 \pm 7 (pré-

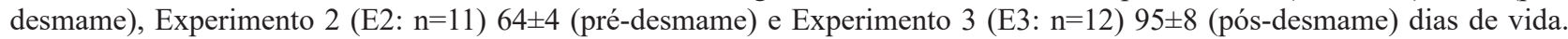
Para todos os experimentos o período experimental foi de 15 dias, assim como foram delineados com dois grupos: controle e tratados com curcumina. Os grupos de curcumina receberam $200 \mathrm{mg}$ do aditivo por animal/dia no leite (pré-desmame) ou em concentrado (pós-desmame). Coletas de fezes e sangue foram realizadas nos dias 0,10 e 15 de experimento para contagem de oocistos de Eimeria por grama de fezes e análise de escore fecal. Do sangue colhido foram realizados: hemograma, perfil oxidante e antioxidante, metabolismo proteico, lipídico, glicose, além da pesagem dos animais. Também foi realizado análise de digestibilidade da dieta total ofertada aos animais do Experimento 3 (pós-desmame). Resultados: Independentemente da fase, os animais que receberam curcumina tiveram maior ganho de peso do dia 0 a 15 (E1, E2 e E3, p=0,04, 0,001 e 0,001 , respectivamente), provavelmente devido ao aumento da digestibilidade ao feno e concentrado após $72 \mathrm{~h}$ ( $\mathrm{p}=0,03$ e 0,02, respectivamente). Nos bezerros suplementados, observou-se menor nível de oxidantes (substâncias reativas ao ácido tiobarbitúrico e espécies reativas de oxigênio), ou seja, os níveis séricos de radicais livres e a peroxidação lipídica foram menores. Isto foi provavelmente devido a antioxidantes enzimáticos glutationa S-transferase (E1, E2 e E3, p=0,001, 0,001 e 0,02 , respectivamente), catalase $(E 1, p=0,001)$ e superóxido dismutase $(E 3, p=0,001)$ aumentando nestes animais tratados no dia 15. Além disso, bezerros recebendo curcumina tiveram menores níveis de infecção por Eimeria durante o período experimental e significativos no dia 15 (E1 e E2, p=0,02 e 0,001, respectivamente). Conclusão: A suplementação de curcumina aumenta o potencial coccidiostático e favorece o ganho de peso.

Palavras-chave: antioxidante; bezerros; crescimento do gado; curcumina; Eimeria; estresse animal; parasitologia; suplementação.

\section{Introduction}

The production phase is a challenging period in calves, mainly due to the fact that the animal is born without antibodies and depends on the prompt and efficient intake of colostrum (Santos et al., 2010). Extrinsic factors such as the quality of the facilities can affect the comfort of the calf, potentially affecting its health. Lack of hygiene can favor pathogen growth (Mota et al., 2000) causing diarrhea, pneumonia and poor performance, with high morbidity and mortality in severe cases (Butler et al., 2000).

Several drugs have been used to overcome or minimize these problems in calf rearing. However, when they are used excessively, cases of microorganism resistance can occur (Obaidat et al., 2018). Generally, treatments performed at this time are costly, require more labor, and can potentially risk the calf due to drug inefficacy. Faced with these challenges, alternatives are sought for prevention, control, and cure of diseases early in life. Supplementation with plant extracts can be justified if they augment immune responses and antioxidant levels, leading to better animal performance (Busquet et al., 2000). An additive known as curcumin has been studied in poultry, showing promise in terms of improved meat quality and growth performance (Fascina et al., 2012; Kim et al., 2013; Zhang et al., 2015).

Curcumin is extracted from Curcuma longa L., a plant belonging to the family Zingiberaceae, popularly known as saffron (Maia et al., 1995). The substance is found in the rhizome of the plant. The active compound is thought to be diphenylmethane, a hydrophobic polyphenol that confers color and aromatic characteristics (Bezerra et al., 2013). The beneficial effect of curcumin is related to its structure, i.e. the aromatic ring hydroxyls, the double bonds in the alkene, and the dike tone portion. These confer anti-inflammatory, antibacterial, antiviral, anticancer, antioxidant, and coccidiostatic activities (Almeida et al., 2008; Pelícia et al., 2015). Although it has known benefits in poultry, it is unclear as to whether curcumin may be useful in calves. Therefore, the objective of this study was to evaluate whether the addition of curcumin in the diet of calves at various growth phases (pre- and post-weaning) has positive effects on metabolic profile, coccidiostatic activity and animal performance. 


\section{Materials and Methods}

\section{Ethical Considerations}

The procedures were approved by the Animal Welfare Committee of Universidade do Estado de Santa Catarina (UDESC), Brazil, under protocol number 3067300717.

\section{Curcumin}

Curcumin was purchased from Shaanxi Jiahe Phytochem Ltd, China (99\% pure).

\section{Experimental location}

The study was carried out on a commercial farm located in the municipality of Chapecó, Santa Catarina, Brazil. The experimental period was 15 days and included animals at different phases (pre- and post-weaning). Pre-weaning calves remained in individual pens, receiving four liters of milk per animal/ day, with access to concentrate, hay and water ad libitum, while the post-weaning calves were housed in collective pens (six animals/ pen). The diet offered was based on hay and concentrate with ad libitum access to water.

\section{Experimental design}

First, fecal collection and analysis was performed to quantify the number of Eimeria oocysts per gram of feces to identify and allocate groups. Three groups of Holstein calves were divided according to age, as follows: Experiment 1 (E1) included 10 animals at the beginning of nursing, average age $18 \pm 7$ days (control group $(\mathrm{n}=5)$ and treated group $(\mathrm{n}=5)$ ); Experiment 2 (E2) included 11 calves, who were close to weaning age, average age $64 \pm 4$ days (treated group $(\mathrm{n}=6)$ and a control group $(\mathrm{n}=5)$ ); and Experiment 3 (E3) included 12 weaned animals, age $95 \pm 8$ days (treated group $(\mathrm{n}=6)$ and a control group $(\mathrm{n}=6))$. The number of coccidian oocytes and age of the animals was used to separate the animals randomly into control and experimental groups.
During the first $24 \mathrm{~h}$ after birth calves received four liters of colostrum, followed by transition to milk (days 2 to 5). Subsequently, on post-natal day (PND) 6 the animals were fed twice a day with 4 liters of pasteurized milk using a bottle (Experiments 1 and 2). The animals in the treated group received $50 \mathrm{mg}$ of curcumin per liter of milk, totaling $200 \mathrm{mg}$ per day. Animals in Experiment 3 ingested $100 \mathrm{mg}$ of curcumin $/ \mathrm{kg}$ of concentrate supplement (2 $\mathrm{kg}$ concentrate per day were given to each calf), giving approximately $200 \mathrm{mg}$ of curcumin per day. All animals were fed individually.

To the best of our knowledge, this is the first study conducted on curcumin supplementation for calves. Other studies have included curcumin in diets of dairy sheep $(80 \mathrm{mg} /$ animal/day) and lambs (52, 100 and $200 \mathrm{mg} /$ $\mathrm{kg}$ feed) (Cervantes-Valencia et al., 2016; Jaguezeski et al., 2018; Molosse et al., 2019). There is no established dose of curcumin for ruminant diets. Based on the referred experiments, we chose $200 \mathrm{mg} /$ animal/day.

\section{Sample collection}

Blood samples were taken on days 0,10 and 15 of the experiment, via jugular venipuncture. Blood was collected in vacuum tubes either with or without anticoagulants (sodium citrate and $100 \%$ EDTA). Samples were stored in isothermal ice boxes at $10^{\circ} \mathrm{C}$ for transport to the laboratory. Samples collected in tubes without anticoagulant were centrifuged at 7,000 rpm for 10 minutes to obtain serum.

Feces were collected directly from the rectal ampulla on days 0,10 and 15 of the experiment. Samples were stored on ice for transport to the laboratory, where they were maintained at $5{ }^{\circ} \mathrm{C}$ until analysis.

\section{Body weight}

At collection dates, the animals were weighed using a commercial measuring tape that correlates the thoracic perimeter with a 
weight estimate (Reis et al., 2008). Animals were measured with the four limbs resting on the ground and the head looking forward.

\section{Hemogram}

Hemogram was performed within two hours of sample collection. Erythrocyte, total leukocyte, and hemoglobin counts were performed using a semi-automatic blood cell counter (model CELM CC530). Hematocrit was determined using capillary tubes, centrifuged for 5 minutes at $10,000 \mathrm{rpm}$. The leukocyte differential was performed by staining the blood smear with a Panótico Rápido kit.

\section{Serum biochemistry}

Serum levels of total proteins, albumin, globulin, urea, cholesterol, glucose, aspartate aminotransferase (AST), gamma glutamyl transferase (GGT) and creatinine were evaluated using a commercial kit (ANALISA ${ }^{\circledR}$ ) on a semi-automatic equipment (BIO PLUS 2000®). Globulin levels were obtained by subtraction (total proteins - albumin).

\section{Antioxidant enzymes}

In whole blood, catalase (CAT) enzyme activity was analyzed according to the technique described by Nelson and Kiesow (1972), where the enzyme activity is determined as hydrogen peroxidation and measured with absorbance at $240 \mathrm{~nm}$. Results are expressed in $\mathrm{U}$ CAT $/ \mathrm{mL}$. Superoxide dismutase (SOD) was determined in whole blood according to a method described by McCord and Fridovich (1969). Results are expressed as U SOD/mL. Activity of the antioxidant enzyme glutathione S-transferase (GST) was measured using the method described by Habig et al. (1974). Results are expressed as nmol/mg protein.

\section{Oxidants}

In plasma, levels of reactive oxygen species
(ROS) were measured according to a method described by Ali et al. (1992). Absorbance was read at $488 \mathrm{~nm}$ and emission at $525 \mathrm{~nm}$, measured in a LS-50 spectrophotometer. Free radical formation was quantified from a standard DCF curve in methanol $(0.05-1 \mu \mathrm{M})$, and the results were expressed as $\mathrm{U} \mathrm{DCF} / \mathrm{mL}$.

Lipid peroxidation was determined by the levels of thiobarbituric acid reactive substances (TBARS) according to a method described by Jentzsch et al. (1996). The results were expressed as nmol malondialdehyde/ml.

\section{Stool parasitology}

Fecal samples were used to determine the number of Eimeria oocysts per gram of feces, using a technique adapted from Faust and collaborators (Monteiro, 2010).

\section{Fecal score}

The fecal score determination is a simple methodology for determining the condition of the stools. The fecal scoring system we used was described by Larson et al. (1977), where the scale for fluidity was as follows: 1, normal; 2, soft; 3 , watery; and 4, fluid. For consistency, the score was as follows: 1 , normal; 2 , frothy, 3 , mucous; 4, sticky; and 5: very firm. Color was scored as follows: 1, white; 2, gray; 3, yellow; 4, brown; 5 , red (blood present); 6, green; and 7, very dark. Finally, the odor score was as follows: 1, normal; 2 , mildly malodorous; and 3 , highly malodorous.

\section{In vitro digestibility}

For determination of in vitro apparent digestibility, samples of oat hay and commercial concentrate were prepared to simulate the total diet supplied to the calves. We used a DAISY ${ }^{\circledR}$ ruminal fermenter, and feces from calves served as the inoculum. The feces were collected directly from the rectal ampulla, yielding approximately $800 \mathrm{~g}$. Incubation was performed according to a method described by Alcalde et al. (2001) in two stages of fermentation $(48 \mathrm{~h}$ 
ruminal fermentation followed by 24 for acid and enzymatic digestion). Half of the replicates were removed at $48 \mathrm{~h}$ of incubation, and the other half were digested for $72 \mathrm{~h}$.

Samples were ground using a knife-type mill with a $1 \mathrm{~mm}$ grid. Afterwards, $250 \mathrm{mg}$ of each food sample was incubated in TNT bags (Lopes et al., 2014) in quadruplicates. In two of the fermenter vials, curcumin was added at a dose of $0.0125 \mathrm{mg}$ for each 250 $\mathrm{mg}$ food sample, simulating $250 \mathrm{mg}$ per kilogram of ingested concentrate per animal.

\section{Dietary analysis}

Feed samples were collected from the total diet provided (concentrate and hay) for all calves in the three experiments (Table 1). Dry matter, mineral matter, ether extract and crude protein were measured following the method described by Silva and Queiroz (2006). In addition, neutral detergent fiber and acid detergent fiber were analyzed following the methodology described by Van Soest (1994).

Table 1. Nutritional composition of oat hay and concentrate supplied to calves.

\begin{tabular}{lcc}
\hline $\begin{array}{l}\text { Composition } \\
\text { (\% in dry matter) }\end{array}$ & Hay & Concentrate \\
\hline Dry Matter & 95.5 & 89.0 \\
Mineral Protein & 7.5 & 7.3 \\
Crude Protein & 12.0 & 16.0 \\
Ethereal Extract & 1.4 & 2.8 \\
Neutral Detergent Fiber & 61.0 & 49.4 \\
Acid Detergent Fiber & 36.2 & 10.8 \\
TDN & & \\
\hline
\end{tabular}

\section{Statistical analysis}

Data were analyzed using descriptive statistics for contingency of information. Further assumptions as weight, weight gain, oocyst number, biochemistry and blood cell parameters were presented as descriptive (mean and standard deviation). Tabulated data was tested for normality (Shapiro), and was not normal (weight, OOPG, leukocytes, neutrophils, lymphocytes, monocytes, eosinophils, CAT, ROS, SOD, GST, glucose and cholesterol); therefore, it was transformed to logarithm for normalization purposes. Comparisons between groups were made using the Student test (t-test), and considered significant when $p<0.05$. Oneway ANOVA was performed using repeated measurements to test for differences in the parameters over time (considering blocks of control and treated group). Feces scores were analyzed using a Chi-square independence test, aimed to evaluate the presence or absence of the score. Statistical manipulation was performed using R-language, v.3.1 (R Development Core Team 2012).

The post-hoc power for the groups in the three experiments was calculated. The mean of each group and SD with an alpha of 0.05 was used, achieving reasonable power: 92.2 (Experiment 1), 90.3 (Experiment 2) and 88.4\% (Experiment3).

\section{Results}

\section{Body weight and weight gain}

Body weight did not differ between groups $(p>0.05)$ in any of the experiments (E1, E2 and E3), or three time periods (days 0, 10 and 15) (Table 2). Over time, no difference in body weight of the animals from the three experiments was observed ( $p>0.05$; Table 2$)$. Regardless of the age when curcumin was added to the diet, the supplement increased calf weight gain at days 0 to 15 (E1, E2 and E3; p-values: 0.04, 0.001 and 0.001, respectively, Table 2). The large individual weight variation at the beginning of the experiments could be the cause of the differences in weight gain observed.

\section{Fecal score and coccidial infection}

No difference was observed on fecal scoring between groups (for fluidity, consistency, color, or odor) in the three experiments $(p<0.05)$. However, the number of coccidian oocysts in the animals of Experiment 1 at day 15 was 
lower in the treated one, compared with that of the control group.

In Experiment 2, a similar result was also observed at day 15 , that is, reduced oocyst count in feces (Table 2).
Over time, there was a decrease in OOPG of calves that received curcumin in the diet (E1 and E2) $(p<0.05$; Table 2). Importantly, animals showed no clinical signs of disease during the experiment, and therefore there was no need for drug treatment.

Table 2. Mean values and standard deviation for weight, weight gain and Eimeria spp. oocysts per gram of feces (OOPG) found on days 0,10 and 15 of the experiment for animals of the control and treated groups.

\begin{tabular}{|c|c|c|c|c|c|c|c|c|c|c|}
\hline \multirow{2}{*}{ Variables } & \multirow{2}{*}{ Day } & \multicolumn{3}{|c|}{ EXPERIMENT 1} & \multicolumn{3}{|c|}{ EXPERIMENT 2} & \multicolumn{3}{|c|}{ EXPERIMENT 3} \\
\hline & & CONTROL & TREATED & $p^{1}$ & CONTROL & TREATED & $\mathrm{p}^{1}$ & CONTROL & TREATED & $\mathbf{p}^{1}$ \\
\hline \multirow{4}{*}{$\begin{array}{l}\text { Weight* } \\
\text { (kg) }\end{array}$} & 0 & $46.8 \pm 6.3$ & $50.6 \pm 6.2$ & 0.85 & $72.8 \pm 4.7$ & $70.8 \pm 10$ & 0.89 & $114.3 \pm 11.4$ & $110 \pm 12.1$ & 0.85 \\
\hline & 10 & $49 \pm 6.9$ & $54.4 \pm 7.3$ & 0.74 & $74.6 \pm 7.3$ & $77.6 \pm 8.5$ & 0.67 & $118.9 \pm 9.6$ & $116 \pm 11$ & 0.92 \\
\hline & 15 & $49.8 \pm 7.7$ & $55.6 \pm 6.7$ & 0.79 & $77.6 \pm 7.5$ & $80.8 \pm 8.7$ & 0.91 & $122 \pm 11$ & $123 \pm 10$ & 0.94 \\
\hline & $\mathbf{p}^{2}$ & 0.45 & 0.21 & & 0.35 & 0.30 & & 0.42 & 0.19 & \\
\hline \multirow{2}{*}{$\begin{array}{l}\text { Weight } \\
\text { gain* }(\mathrm{kg})\end{array}$} & $0-10$ & $2.2 \pm 1.6$ & $3.8 \pm 2.1$ & 0.13 & $1.8 \pm 1.5$ & $7 \pm 3.4$ & 0.001 & $4.6 \pm 2.4$ & $6 \pm 3.3$ & 0.21 \\
\hline & $0-15$ & $3.0 \pm 1.4$ & $5.0 \pm 1.8$ & 0.04 & $4.8 \pm 2.7$ & $10 \pm 4.1$ & 0.001 & $7.7 \pm 2.8$ & $13 \pm 4.5$ & 0.001 \\
\hline \multirow{4}{*}{ OOPG* } & 0 & $159.9 \pm 180.7$ & $280 \pm 196.7^{\mathrm{a}}$ & 0.84 & $140 \pm 210$ & $158 \pm 228^{a}$ & 0.76 & $66.8 \pm 87.5$ & $33.3 \pm 51$ & 0.74 \\
\hline & 10 & $473.6 \pm 623.0$ & $28 \pm 62.6^{\mathrm{b}}$ & 0.09 & $144 \pm 202$ & $3.2 \pm 7.1^{\mathrm{b}}$ & 0.07 & $128 \pm 292.4$ & $0 \pm 0$ & 0.26 \\
\hline & 15 & $305.8 \pm 281.7$ & $15.3 \pm 34.3^{\mathrm{b}}$ & 0.02 & $68.5 \pm 59.7$ & $0.0 \pm 0.0^{\mathrm{b}}$ & 0.001 & $69.6 \pm 79.4$ & $0 \pm 0$ & 0.08 \\
\hline & $p^{2}$ & 0.57 & 0.04 & & 0.60 & 0.001 & & 0.46 & 0.12 & \\
\hline
\end{tabular}

*Transformed values for logarithm; Experiment 1: heifers with $18 \pm 7$ days of life; Experiment 2: heifers with $64 \pm 4$ days of life; Experiment 3 : heifers with $95 \pm 8$ days of life. Animals from experiment 1 and 2 were in the pre-weaning phase, and experiment 3 was in the post-weaning phase. In the three experiments we had two independent groups, that is, one control group and one treated group (supplemented with curcumin in the diet). ${ }^{1} \mathrm{p}<0.05$ shows difference between groups; ${ }^{2} \mathrm{p}<0.05$ shows difference over time in each group (day 0 vs 10 , day 0 vs 15 , day 10 vs 15 ). When $p<0.05$ the difference between periods (day) was identified by different superscript letters $\left({ }^{a}, b\right)$ within the same column.

\section{Hemogram}

Erythrocyte count, hemoglobin concentration, hematocrit, neutrophil, monocyte, and eosinophil numbers did not vary between groups in any of the experiments $(\mathrm{p}>0.05)$. Leukocyte and lymphocyte count also did not differ between groups in E1 and E2.
In Experiment 3 (E3), leukocytes counts were lower in the treated group compared with the control group at day 15 (Table 3). This decrease in total leukocytes number is related to the decreased lymphocytes in the same period (Table 3). However, when these variables were evaluated over time, we noticed an increase in the number of total leukocytes as a consequence of the increase of lymphocytes only in the control group.

Table 3. Mean values and standard deviation for erythrocyte, hemoglobin, hematocrit, leukocyte, lymphocyte, neutrophil, monocyte and eosinophil found on days 0,10 and 15 of the experiment for control and treated animals.

\begin{tabular}{lcccccccccc}
\hline \multirow{2}{*}{ VARIABLE } & DAY & \multicolumn{3}{c}{ EXPERIMENT 1 } & \multicolumn{3}{c}{ EXPERIMENT 2 } & \multicolumn{2}{c}{ EXPERIMENT 3 } \\
\cline { 2 - 10 } & & CONTROL & TREATED & $\mathbf{p}^{\mathbf{1}}$ & CONTROL & TREATED & $\mathbf{p}^{\mathbf{1}}$ & CONTROL $^{\text {TREATED }}$ & $\mathbf{p}^{\mathbf{1}}$ \\
\hline & 0 & $4.7 \pm 1.2$ & $4.4 \pm 0.7$ & 0.89 & $3.9 \pm 0.26$ & $3.9 \pm 0.9$ & 0.94 & $4.87 \pm 0.24$ & $4.8 \pm 0.8$ & 0.96 \\
$\begin{array}{l}\text { Erythrocytes } \\
\left(\mathrm{x} 10^{6} / \mu \mathrm{L}\right)\end{array}$ & 10 & $3.9 \pm 0.83$ & $4.8 \pm 0.94$ & 0.45 & $4.6 \pm 0.68$ & $4.35 \pm 0.77$ & 0.86 & $5.05 \pm 0.72$ & $4.4 \pm 0.5$ & 0.73 \\
& 15 & $4 \pm 0.84$ & $4.6 \pm 0.86$ & 0.54 & $4.9 \pm 0.64$ & $4.9 \pm 1$ & 0.95 & $5.1 \pm 0.68$ & $5.29 \pm 0.7$ & 0.92
\end{tabular}




\begin{tabular}{|c|c|c|c|c|c|c|c|c|c|c|}
\hline & $\mathbf{p}^{2}$ & 0.43 & 0.75 & & 0.12 & 0.36 & & 0.74 & 0.31 & \\
\hline \multirow{4}{*}{$\begin{array}{l}\text { Hemoglobin } \\
(\mathrm{g} / \mathrm{dL})\end{array}$} & 0 & $9.1 \pm 0.9$ & $8.6 \pm 0.81$ & 0.88 & $9.1 \pm 0.7$ & $8.8 \pm 0.6$ & 0.87 & $9.5 \pm 0.67$ & $9 \pm 0.97$ & 0.89 \\
\hline & 10 & $8.7 \pm 0.6$ & $8.6 \pm 0.64$ & 0.97 & $9.5 \pm 0.69$ & $8.8 \pm 0.5$ & 0.23 & $9.2 \pm 3.6$ & $8.6 \pm 4$ & 0.70 \\
\hline & 15 & $8.8 \pm 0.7$ & $8.7 \pm 0.87$ & 0.90 & $9.8 \pm 0.9$ & $9.9 \pm 0.4$ & 0.91 & $9.2 \pm 0.5$ & $9.4 \pm 1.7$ & 0.93 \\
\hline & $\mathbf{p}^{2}$ & 0.81 & 0.90 & & 0.62 & 0.09 & & 0.92 & 0.70 & \\
\hline \multirow{4}{*}{$\begin{array}{l}\text { Hematocrit } \\
(\%)\end{array}$} & 0 & $34.6 \pm 2.8$ & $33.2 \pm 2.5$ & 0.95 & $33 \pm 3.1$ & $32.8 \pm 1.9$ & 0.88 & $36.1 \pm 3.7$ & $34.3 \pm 3.5$ & 0.88 \\
\hline & 10 & $34.7 \pm 2.6$ & $32.3 \pm 2.4$ & 0.89 & $35.6 \pm 1.8$ & $34.8 \pm 1.7$ & 0.85 & $35.8 \pm 2.8$ & $32 \pm 2.5$ & 0.75 \\
\hline & 15 & $33.4 \pm 2.7$ & $32 \pm 3.1$ & 0.96 & $36.6 \pm 4$ & $35.1 \pm 4.8$ & 0.90 & $32 \pm 3.1$ & $29 \pm 1.7$ & 0.19 \\
\hline & $\mathbf{p}^{2}$ & 0.94 & 0.95 & & 0.75 & 0.81 & & 0.63 & 0.06 & \\
\hline \multirow{4}{*}{$\begin{array}{l}\text { Leukocytes* } \\
\left(\times 10^{3} / \mu \mathrm{L}\right)\end{array}$} & 0 & $8.7 \pm 4$ & $9.4 \pm 0.9$ & 0.84 & $8.2 \pm 1.98$ & $8 \pm 1.99$ & 0.92 & $6.8 \pm 2^{\mathrm{b}}$ & $7.6 \pm 1.7$ & 0.68 \\
\hline & 10 & $9.73 \pm 3.3$ & $9.57 \pm 1.5$ & 0.95 & $7.68 \pm 1.82$ & $7.55 \pm 1.2$ & 0.90 & $7.2 \pm 1.36^{\mathrm{b}}$ & $7.4 \pm 1.2$ & 0.79 \\
\hline & 15 & $7.9 \pm 1.9$ & $6.5 \pm 2.3$ & 0.56 & $7.9 \pm 0.7$ & $8.76 \pm 2.7$ & 0.74 & $10.4 \pm 1^{\mathrm{a}}$ & $7.5 \pm 1.1$ & 0.001 \\
\hline & $\mathbf{p}^{2}$ & 0.55 & 0.71 & & 0.68 & 0.73 & & 0.01 & 0.81 & \\
\hline \multirow{4}{*}{$\begin{array}{l}\text { Lymphocytes* } \\
\left(\times 10^{3} / \mu \mathrm{L}\right)\end{array}$} & 0 & $4.5 \pm 2$ & $4.8 \pm 0.9$ & 0.78 & $3.9 \pm 0.8$ & $4.6 \pm 1.65$ & 0.67 & $3.56 \pm 1.4^{\mathrm{b}}$ & $3.5 \pm 0.8$ & 0.96 \\
\hline & 10 & $3.9 \pm 1.7$ & $4.7 \pm 1.5$ & 0.45 & $4.2 \pm 1.5$ & $3.5 \pm 0.8$ & 0.36 & $4 \pm 1.2^{\mathrm{b}}$ & $4.1 \pm 1.1$ & 0.93 \\
\hline & 15 & $4.6 \pm 1.6$ & $4.0 \pm 2.3$ & 0.56 & $5.2 \pm 1.1$ & $5.9 \pm 1.8$ & 0.44 & $6.98 \pm 1.1^{\mathrm{a}}$ & $4.7 \pm 1.2$ & 0.01 \\
\hline & $\mathbf{p}^{2}$ & 0.59 & 0.33 & & 0.24 & 0.11 & & 0.001 & 0.20 & \\
\hline \multirow{4}{*}{$\begin{array}{l}\text { Neutrophils* } \\
\left(\mathrm{x} 10^{3} / \mu \mathrm{L}\right)\end{array}$} & 0 & $3.4 \pm 1.9$ & $4.3 \pm 0.4$ & 0.36 & $3.8 \pm 1.2$ & $3 \pm 0.64$ & 0.71 & $2.97 \pm 1$ & $3.58 \pm 0.9$ & 0.45 \\
\hline & 10 & $5.1 \pm 2.3$ & $4.2 \pm 3.7$ & 0.40 & $3 \pm 0.7$ & $3.4 \pm 0.62$ & 0.36 & $2.98 \pm 0.98$ & $3.16 \pm 1$ & 0.72 \\
\hline & 15 & $2.9 \pm 1.2$ & $2.3 \pm 1.5$ & 0.69 & $2.4 \pm 0.8$ & $2.5 \pm 1.4$ & 0.92 & $3 \pm 0.7$ & $2.9 \pm 1.77$ & 0.96 \\
\hline & p2 & 0.18 & 0.07 & & 0.09 & 0.25 & & 0.79 & 0.72 & \\
\hline \multirow{4}{*}{$\begin{array}{l}\text { Monocytes* } \\
\left(\mathrm{x} 10^{3} / \mu \mathrm{L}\right)\end{array}$} & 0 & $0.73 \pm 0.6$ & $0.26 \pm 0.16$ & 0.74 & $0.27 \pm 0.18$ & $0.21 \pm 0.15$ & 0.77 & $0.21 \pm 0.18$ & $0.32 \pm 0.19$ & 0.66 \\
\hline & 10 & $0.53 \pm 2.3$ & $0.4 \pm 0.4$ & 0.84 & $0.31 \pm 0.25$ & $0.37 \pm 0.3$ & 0.85 & $0.2 \pm 0.27$ & $0.21 \pm 0.16$ & 0.95 \\
\hline & 15 & $0.36 \pm 0.2$ & $0.2 \pm 0.16$ & 0.90 & $0.23 \pm 0.11$ & $0.26 \pm 0.3$ & 0.86 & $0.35 \pm 0.1$ & $0.21 \pm 0.13$ & 0.11 \\
\hline & $\mathbf{p}^{2}$ & 0.32 & 0.48 & & 0.67 & 0.63 & & 0.59 & 0.53 & \\
\hline \multirow{4}{*}{$\begin{array}{l}\text { Eosinophils* } \\
\left(\times 10^{3} / \mu \mathrm{L}\right)\end{array}$} & 0 & $0.06 \pm 0.08$ & $0.08 \pm 0.14$ & 0.90 & $0.14 \pm 0.15$ & $0.08 \pm 0.09$ & 0.87 & $0.08 \pm 0.15$ & $0.15 \pm 0.15$ & 0.93 \\
\hline & 10 & $0.20 \pm 0.25$ & $0.27 \pm 0.35$ & 0.85 & $0.07 \pm 0.11$ & $0.17 \pm 0.18$ & 0.60 & $0.07 \pm 0.11$ & $0.0 \pm 0.0$ & 0.74 \\
\hline & 15 & $0.02 \pm 0.04$ & $0.03 \pm 0.06$ & 0.95 & $0.08 \pm 0.18$ & $0.14 \pm 0.69$ & 0.68 & $0.02 \pm 0.04$ & $0.01 \pm 0.02$ & 0.88 \\
\hline & $\mathbf{p}^{2}$ & 0.51 & 0.46 & & 0.62 & 0.54 & & 0.65 & 0.47 & \\
\hline
\end{tabular}

*Transformed values for logarithm; Experiment 1: heifers with 18 \pm 7 days of life; Experiment 2: heifers with $64 \pm 4$ days of life; Experiment 3 : heifers with 95 \pm 8 daysoflife.AnimalsfromExperiment 1 and 2 werein thepre-weaningphase, andExperiment 3 wasinthepost-weaningphase. Inthethreeexperimentswehad two independent groups, that is, one control group and one treated group (supplemented with curcumin in the diet). ${ }^{1} \mathrm{p}<0.05$ shows difference between groups. ${ }^{2} \mathrm{p}<0.05$ shows difference over time in each group (day 0 vs 10 , day 0 vs 15 , day 10 vs 15 ). When $p<0.05$ the difference between periods (day) was identified by different superscript letters $(\mathrm{a}, \mathrm{b})$ within the same column.

\section{Serum biochemistry}

In Experiment 1, we observed high total protein and globulin levels in animals receiving curcumin at day 15. However, in Experiment 3 , total protein and globulin were lower in the treated group compared with the control group (Table 4). In Experiments 1 and 2, albumin levels were lower in the treated group compared to the control group (Table 4). For other parameters, including urea, glucose, cholesterol, AST, GGT and creatinine, no statistical difference was observed between groups. 
Over time, total protein levels decreased as a consequence of the reduction of globulins in the animals on the treated group of E2 and E3 (Table 4). In E1, there was an increase of globulins in both groups over time. Albumin also decreased as time passed in the treated group of E1. Only in E3 urea levels increased over time in both groups (Table 4). Glucose levels decreased in all groups of the three experiments, except for the E1 control group. Cholesterol and creatinine levels, as well as AST and GGT activity did not differ over time in the animals from the three experiments (Table 4).

Table 4. Mean values and standard deviation for total proteins, albumin, globulin, urea, glucose, cholesterol, aspartate aminotransferase (AST), gamma glutamyl transferase (GGT) and creatinine found on days 0, 10 and 15 of each experiment for control and treated animals.

\begin{tabular}{|c|c|c|c|c|c|c|c|c|c|c|}
\hline \multirow{2}{*}{ Variable } & \multirow{2}{*}{ Day } & \multicolumn{3}{|c|}{ EXPERIMENT 1} & \multicolumn{3}{|c|}{ EXPERIMENT 2} & \multicolumn{3}{|c|}{ EXPERIMENT 3} \\
\hline & & CONTROL & TREATED & $\mathrm{p}^{1}$ & CONTROL & TREATED & $p^{1}$ & CONTROL & TREATED & $p^{1}$ \\
\hline \multirow{4}{*}{ Total protein $(\mathrm{g} / \mathrm{dL})$} & 0 & $6.1 \pm 1.9$ & $6.6 \pm 1.19$ & 0.85 & $8.3 \pm 1.8$ & $9 \pm 1.34^{\mathrm{a}}$ & 0.80 & $8.1 \pm 1.6$ & $9.1 \pm 1.3^{\mathrm{a}}$ & 0.56 \\
\hline & 10 & $6.6 \pm 1.16$ & $6.8 \pm 1.3$ & 0.80 & $7.52 \pm 2.6$ & $6.3 \pm 1.2^{\mathrm{ab}}$ & 0.74 & $7.1 \pm 1.7$ & $6.2 \pm 1.6^{\mathrm{ab}}$ & 0.62 \\
\hline & 15 & $5.5 \pm 0.3$ & $6.9 \pm 0.3$ & 0.01 & $6.4 \pm 0.3$ & $6.7 \pm 0.6^{b}$ & 0.88 & $7.3 \pm 0.6$ & $5.9 \pm 0.6^{b}$ & 0.04 \\
\hline & $\mathrm{p}^{2}$ & 0.25 & 0.76 & & 0.31 & 0.01 & & 0.52 & 0.001 & \\
\hline \multirow{4}{*}{ Albumin (g/dL) } & 0 & $4.4 \pm 1.7$ & $4.5 \pm 0.8^{\mathrm{a}}$ & 0.95 & $3.8 \pm 1$ & $3.5 \pm 1.2$ & 0.94 & $4 \pm 1.2$ & $4 \pm 1$ & 0.94 \\
\hline & 10 & $2.7 \pm 0.3$ & $3 \pm 0.9^{\mathrm{ab}}$ & 0.84 & $3.3 \pm 2.1$ & $3.4 \pm 0.9$ & 0.92 & $2.9 \pm 0.3$ & $3.1 \pm 0.8$ & 0.86 \\
\hline & 15 & $2.9 \pm 0.4$ & $2.3 \pm 0.2^{b}$ & 0.03 & $4.16 \pm 0.8$ & $3.2 \pm 0.3$ & 0.05 & $2.8 \pm 0.4$ & $3.08 \pm 0.4$ & 0.89 \\
\hline & $\mathrm{p}^{2}$ & 0.22 & 0.01 & & 0.58 & 0.84 & & 0.26 & 0.28 & \\
\hline \multirow{2}{*}{ Globulin } & 0 & $1.66 \pm 0.2^{b}$ & $2.06 \pm 0.5^{b}$ & 0.86 & $4.54 \pm 1.6$ & $5.58 \pm 0.98^{\mathrm{a}}$ & 0.96 & $4 \pm 1.5$ & $5 \pm 1.4^{\mathrm{a}}$ & 0.76 \\
\hline & 10 & $4 \pm 0.8^{\mathrm{a}}$ & $3.82 \pm 1^{\mathrm{a}}$ & 0.79 & $4.2 \pm 3.2$ & $2.9 \pm 1.5^{\mathrm{b}}$ & 0.13 & $4.1 \pm 1.7$ & $3.1 \pm 0.9^{\mathrm{ab}}$ & 0.47 \\
\hline \multirow[t]{2}{*}{$(\mathrm{g} / \mathrm{dL})$} & 15 & $2.66 \pm 0.5^{\mathrm{ab}}$ & $4.1 \pm 0.3^{\mathrm{a}}$ & 0.02 & $2.7 \pm 1.9$ & $3.5 \pm 0.6^{\mathrm{b}}$ & 0.26 & $4.5 \pm 0.9$ & $2.8 \pm 0.6^{b}$ & 0.001 \\
\hline & $\mathrm{p}^{2}$ & 0.001 & 0.001 & & 0.21 & 0.05 & & 0.74 & 0.001 & \\
\hline \multirow{4}{*}{$\begin{array}{l}\text { Urea* }^{*} \\
(\mathrm{mg} / \mathrm{dL})\end{array}$} & 0 & $28.4 \pm 10.7$ & $34 \pm 14.6$ & 0.83 & $21 \pm 16.8$ & $29.6 \pm 10$ & 0.75 & $18.1 \pm 1.6^{b}$ & $19.5 \pm 5.4^{b}$ & 0.89 \\
\hline & 10 & $20.4 \pm 7.8$ & $32.4 \pm 19.3$ & 0.33 & $20.8 \pm 7$ & $21.1 \pm 10$ & 0.90 & $22.6 \pm 9.6^{\mathrm{ab}}$ & $20 \pm 5.3^{b}$ & 0.84 \\
\hline & 15 & $44 \pm 15$ & $36.2 \pm 11.9$ & 0.24 & $20.4 \pm 6.1$ & $22.3 \pm 4.6$ & 0.86 & $33 \pm 12.7^{\mathrm{a}}$ & $33.6 \pm 6.1^{\mathrm{a}}$ & 0.91 \\
\hline & $\mathbf{p}^{2}$ & 0.06 & 0.65 & & 0.87 & 0.39 & & 0.04 & 0.001 & \\
\hline \multirow[t]{2}{*}{ Glucose* } & 0 & $133.8 \pm 25$ & $129 \pm 16.6^{\mathrm{a}}$ & 0.80 & $170.7 \pm 30^{\mathrm{a}}$ & $161.5 \pm 11.6^{\mathrm{a}}$ & 0.81 & $110 \pm 23.3^{\mathrm{a}}$ & $100 \pm 9^{a}$ & 0.86 \\
\hline & 10 & $103.2 \pm 16$ & $131 \pm 56.2^{\mathrm{ab}}$ & 0.32 & $143.2 \pm 25^{\mathrm{a}}$ & $133.6 \pm 40^{\mathrm{a}}$ & 0.83 & $112 \pm 10.9^{\mathrm{a}}$ & $102 \pm 22.8^{\mathrm{a}}$ & 0.89 \\
\hline \multirow[t]{2}{*}{$(\mathrm{mg} / \mathrm{dL})$} & 15 & $105 \pm 12.1$ & $75 \pm 30.5^{b}$ & 0.10 & $70.0 \pm 12^{b}$ & $76 \pm 17^{b}$ & 0.89 & $71.1 \pm 8.8^{\mathrm{b}}$ & $68.6 \pm 4.5^{b}$ & 0.84 \\
\hline & $\mathrm{p}^{2}$ & 0.12 & 0.05 & & 0.001 & 0.001 & & 0.001 & 0.001 & \\
\hline \multirow[t]{2}{*}{ Cholesterol* } & 0 & $118 \pm 45$ & $121 \pm 52$ & 0.94 & $128.8 \pm 39$ & $107 \pm 34.4$ & 0.75 & $55.6 \pm 18.1$ & $50.6 \pm 13.4$ & 0.79 \\
\hline & 10 & $101 \pm 24$ & $97.4 \pm 38.5$ & 0.96 & $130 \pm 44.1$ & $115 \pm 62$ & 0.69 & $80.1 \pm 27.7$ & $61.8 \pm 21$ & 0.45 \\
\hline \multirow{2}{*}{$(\mathrm{mg} / \mathrm{dL})$} & 15 & $158 \pm 38.2$ & $116 \pm 35$ & 0.65 & $123 \pm 31.1$ & $125 \pm 55.2$ & 0.85 & $65 \pm 20.6$ & $86.3 \pm 34$ & 0.58 \\
\hline & $\mathbf{p}^{2}$ & 0.17 & 0.38 & & 0.45 & 0.36 & & 0.20 & 0.14 & \\
\hline AST & 0 & $25.4 \pm 7.9$ & $24.9 \pm 4.8$ & 0.91 & $27.9 \pm 3.7$ & $28.4 \pm 4.9$ & 0.92 & $32.4 \pm 4.4$ & $30.2 \pm 2.9$ & 0.45 \\
\hline$(\mathrm{U} / \mathrm{L})$ & 10 & $26.7 \pm 5.4$ & $25.7 \pm 5.0$ & 0.88 & $29.7 \pm 7.0$ & $30.1 \pm 3.3$ & 0.93 & $33.7 \pm 5.2$ & $31.5 \pm 5.4$ & 0.56 \\
\hline
\end{tabular}




\begin{tabular}{|c|c|c|c|c|c|c|c|c|c|c|}
\hline & 15 & $28.4 \pm 6.5$ & $28.6 \pm 6.6$ & 0.95 & $30.1 \pm 6.1$ & $30.4 \pm 5.1$ & 0.96 & $32.9 \pm 4.6$ & $30.4 \pm 4.2$ & 0.50 \\
\hline & $\mathrm{p}^{2}$ & 0.42 & 0.39 & & 0.55 & 0.68 & & 0.78 & 0.82 & \\
\hline GGT & 0 & $51.4 \pm 8.7$ & $53.9 \pm 5.8$ & 0.84 & $38.7 \pm 4.9$ & $36.7 \pm 7.3$ & 0.88 & $20.7 \pm 3.8$ & $22.4 \pm 6.7$ & 0.85 \\
\hline \multirow[t]{3}{*}{$(\mathrm{U} / \mathrm{L})$} & 10 & $47.9 \pm 5.6$ & $50.4 \pm 6.7$ & 0.78 & $35.7 \pm 6.9$ & $31.7 \pm 5.5$ & 0.76 & $23.8 \pm 9.1$ & $20.7 \pm 3.9$ & 0.78 \\
\hline & 15 & $46.3 \pm 6.1$ & $48.1 \pm 9.4$ & 0.81 & $34.8 \pm 4.5$ & $32.4 \pm 4.3$ & 0.85 & $20.0 \pm 5.9$ & $19.2 \pm 5.2$ & 0.86 \\
\hline & $p^{2}$ & 0.28 & 0.33 & & 0.51 & 0.46 & & 0.66 & 0.54 & \\
\hline Creatinine & 0 & $1.24 \pm 0.44$ & $1.32 \pm 0.53$ & 0.77 & $1.20 \pm 0.33$ & $1.25 \pm 0.47$ & 0.41 & $1.35 \pm 0.61$ & $1.33 \pm 0.38$ & 0.68 \\
\hline \multirow[t]{3}{*}{$(\mathrm{mg} / \mathrm{dL})$} & 10 & $1.19 \pm 0.16$ & $1.25 \pm 0.80$ & 0.79 & $1.09 \pm 0.54$ & $1.32 \pm 0.27$ & 0.37 & $1.34 \pm 0.29$ & $1.28 \pm 0.65$ & 0.54 \\
\hline & 15 & $1.34 \pm 0.51$ & $1.31 \pm 0.23$ & 0.83 & $1.31 \pm 0.64$ & $1.31 \pm 0.51$ & 0.84 & $1.29 \pm 0.52$ & $1.30 \pm 0.41$ & 0.87 \\
\hline & $\mathbf{p}^{2}$ & 0.87 & 0.84 & & 0.83 & 0.85 & & 0.75 & 0.88 & \\
\hline
\end{tabular}

*Transformed values for logarithm; Experiment 1: heifers with $18 \pm 7$ days of life; Experiment 2: heifers with $64 \pm 4$ days of life; Experiment 3: heifers with $95 \pm 8$ days of life. Animals from Experiment 1 and 2 were in the pre-weaning phase, and Experiment 3 was in the post-weaning phase. In the three experiments we had two independent groups, that is, one control group and one treated group (supplemented with curcumin in the diet). ${ }^{1} \mathrm{p}<0.05$ shows difference between groups. ${ }^{2} \mathrm{p}<0.05$ shows difference over time in each group (day 0 vs 10 , day 0 vs 15 , day 10 vs 15 ). When $p<0.05$ the difference between periods (day) was identified by different superscript letters ( ${ }^{\text {a. b }}$ ) within the same column.

\section{Oxidant and antioxidant profiles}

In the post-weaning phase, animals receiving curcumin during 15 days had a reduction in ROS and TBARS levels compared with control animals (Table 5). In general, the activity of antioxidant enzymes (SOD, GST and CAT) of curcumin-fed calves increased $(\mathrm{p}<0.05)$ compared with the control (Table 5). It is important to note that the enzyme activities did not all change concomitantly, nor did we observe effects in all experiments. However, in general, we observed an antioxidant effect of curcumin.

In both groups of E1 and E3, a reduction in TBARS levels was observed over time (Table 5). ROS levels also decreased in animals of the treated group (only E2). GST activity increased over time in the treated groups for all experiments (E1, E2, E3). Likewise, SOD activity increased in the treated animals from E2 and E3. The CAT activity did not differ over time (Table 5).

Table 5. Mean values and standard deviation for lipid peroxidation (TBARS), oxygen reactive species (ROS), glutathione S-transferase (GST), superoxide dismutase (SOD) and catalase (CAT) found on days 0,10 and 15 of the experiment for animals of the control and treated groups.

\begin{tabular}{|c|c|c|c|c|c|c|c|c|c|c|}
\hline \multirow{2}{*}{ Variable } & \multirow{2}{*}{ Day } & \multicolumn{3}{|c|}{ EXPERIMENT 1} & \multicolumn{3}{|c|}{ EXPERIMENT 2} & \multicolumn{3}{|c|}{ EXPERIMENT 3} \\
\hline & & CONTROL & TREATED & $\mathrm{p}^{1}$ & CONTROL & TREATED & $p^{1}$ & CONTROL & TREATED & $p^{1}$ \\
\hline \multirow{4}{*}{$\begin{array}{l}\text { TBARS } \\
(\mathrm{nmol} / \mathrm{ml})\end{array}$} & 0 & $12.5 \pm 5.2^{\mathrm{a}}$ & $10.7 \pm 3.4^{\mathrm{a}}$ & 0.88 & $9.8 \pm 4$ & $8.2 \pm 6$ & 0.69 & $10.2 \pm 4^{\mathrm{a}}$ & $9.5 \pm 2.1^{\mathrm{a}}$ & 0.87 \\
\hline & 10 & $6 \pm 1.8^{\mathrm{ab}}$ & $5.2 \pm 1^{b}$ & 0.90 & $5.5 \pm 1.2$ & $5.4 \pm 1.2$ & 0.95 & $5.2 \pm 0.5^{\mathrm{ab}}$ & $5 \pm 0.6^{b}$ & 0.92 \\
\hline & 15 & $5.5 \pm 0.6^{b}$ & $4.9 \pm 0.4^{b}$ & 0.86 & $5.1 \pm 0.7$ & $4.8 \pm 0.4$ & 0.85 & $4.1 \pm 1^{b}$ & $2.5 \pm 0.1^{b}$ & 0.001 \\
\hline & $\mathrm{p}^{2}$ & 0.01 & 0.001 & & 0.07 & 0.18 & & 0.001 & 0.001 & \\
\hline \multirow{4}{*}{$\begin{array}{l}\text { ROS }(U \\
\text { DCFA/ } \\
\mu \mathrm{L})\end{array}$} & 0 & $13.4 \pm 10.1$ & $10.7 \pm 4.4$ & 0.84 & $6.4 \pm 2.5$ & $9.2 \pm 5.4^{\mathrm{a}}$ & 0.38 & $7.5 \pm 1.5^{\mathrm{ab}}$ & $6.8 \pm 0.9$ & 0.90 \\
\hline & 10 & $14.3 \pm 0.8$ & $13.95 \pm 0.8$ & 0.96 & $4 \pm 0.5$ & $3.4 \pm 0.4^{b}$ & 0.68 & $4.7 \pm 1.8^{b}$ & $5.1 \pm 1.1$ & 0.82 \\
\hline & 15 & $12.8 \pm 6$ & $12.7 \pm 3.7$ & 0.97 & $4.2 \pm 2.3$ & $6.5 \pm 4.5^{\mathrm{ab}}$ & 0.42 & $14.6 \pm 7.5^{\mathrm{a}}$ & $5.7 \pm 1.7$ & 0.001 \\
\hline & $\mathrm{p}^{2}$ & 0.80 & 0.62 & & 0.08 & 0.001 & & 0.02 & 0.67 & \\
\hline
\end{tabular}




\begin{tabular}{|c|c|c|c|c|c|c|c|c|c|c|}
\hline GST & 0 & $113.4 \pm 43.3$ & $106 \pm 50^{c}$ & 0.74 & $130.6 \pm 50$ & $109.2 \pm 43^{b}$ & 0.45 & $98.4 \pm 36$ & $117 \pm 26.6^{b}$ & 0.22 \\
\hline$(\mu \mathrm{mol} /$ & 10 & $149.4 \pm 59$ & $179.5 \pm 26^{b}$ & 0.65 & $167.2 \pm 28$ & $179.6 \pm 17^{\mathrm{ab}}$ & 0.76 & $103 \pm 38.2$ & $134 \pm 28^{\mathrm{ab}}$ & 0.34 \\
\hline \multirow{2}{*}{$\begin{array}{l}\mathrm{Cdnb} / \\
\min )\end{array}$} & 15 & $148.7 \pm 33$ & $270.3 \pm 25^{\mathrm{a}}$ & 0.001 & $146 \pm 21$ & $214.2 \pm 34.2^{\mathrm{a}}$ & 0.001 & $110.4 \pm 36.1$ & $148.9 \pm 12.7^{\mathrm{a}}$ & 0.02 \\
\hline & $\mathbf{p}^{2}$ & 0.25 & 0.001 & & 0.36 & 0.001 & & 0.58 & 0.05 & \\
\hline \multirow{4}{*}{$\begin{array}{l}\text { SOD } \\
\text { (UI/mg } \\
\text { protein) }\end{array}$} & 0 & $9.5 \pm 2$ & $9.2 \pm 3.3$ & 0.87 & $9.3 \pm 2.5$ & $7.18 \pm 2.5^{\mathrm{ab}}$ & 0.78 & $5.8 \pm 3.6$ & $4.21 \pm 1.3^{b}$ & 0.54 \\
\hline & 10 & $9.4 \pm 1$ & $12.2 \pm 3.3$ & 0.13 & $7 \pm 5.2$ & $5.3 \pm 1.7^{b}$ & 0.74 & $7.18 \pm 3.0$ & $6.3 \pm 3.8^{\mathrm{ab}}$ & 0.71 \\
\hline & 15 & $13.3 \pm 2.8$ & $12.3 \pm 3.8$ & 0.89 & $11.6 \pm 3.6$ & $10.5 \pm 2.7^{\mathrm{a}}$ & 0.92 & $5.4 \pm 1.2$ & $7.9 \pm 1.2^{\mathrm{a}}$ & 0.04 \\
\hline & $\mathrm{p}^{2}$ & 0.06 & 0.29 & & 0.35 & 0.001 & & 0.44 & 0.001 & \\
\hline \multirow{2}{*}{$\begin{array}{l}\text { CAT } \\
(\mathrm{nmol} / \mathrm{mg}\end{array}$} & 0 & $5 \pm 3.4$ & $4.1 \pm 1.2$ & 0.85 & $3.88 \pm 0.7$ & $4.64 \pm 2.3$ & 0.65 & $5.8 \pm 22$ & $4.8 \pm 1.4$ & 0.42 \\
\hline & 10 & $3.4 \pm 0.8$ & $4.3 \pm 2.6$ & 0.83 & 4.w. 2 & $3.4 \pm 0.6$ & 0.71 & $5.1 \pm 2$ & $5.14 \pm 1.7$ & 0.89 \\
\hline \multirow[t]{2}{*}{ protein) } & 15 & $2.9 \pm 1$ & $4.4 \pm 0.8$ & 0.001 & $5.39 \pm 3.6$ & $4.6 \pm 1.4$ & 0.47 & $5.1 \pm 1.7$ & $5 \pm 2$ & 0.87 \\
\hline & $\mathbf{p}^{2}$ & 0.21 & 0.75 & & 0.23 & 0.55 & & 0.46 & 0.78 & \\
\hline
\end{tabular}

*Transformed values for logarithm; Experiment 1: heifers with $18 \pm 7$ days of life; Experiment 2: heifers with $64 \pm 4$ days of life; Experiment 3: heifers with $95 \pm 8$ days of life. Animals from Experiment 1 and 2 were in the pre-weaning phase, and Experiment 3 was in the post-weaning phase. In the three experiments we had two independent groups, that is, one control group and one treated group (supplemented with curcumin in the diet).

\section{Digestibility}

After incubation for $48 \mathrm{~h}$ (simulating ruminal digestion) no differences were found between treatments $(p>0.05)$, between groups (without and with curcumin) for digestibility in hay or concentrate (Figure 1). However, curcumin combined with hay and concentrate at 72 hours increased the digestibility 18.1 and $29.0 \%$, respectively $(\mathrm{p}<0.05)$.

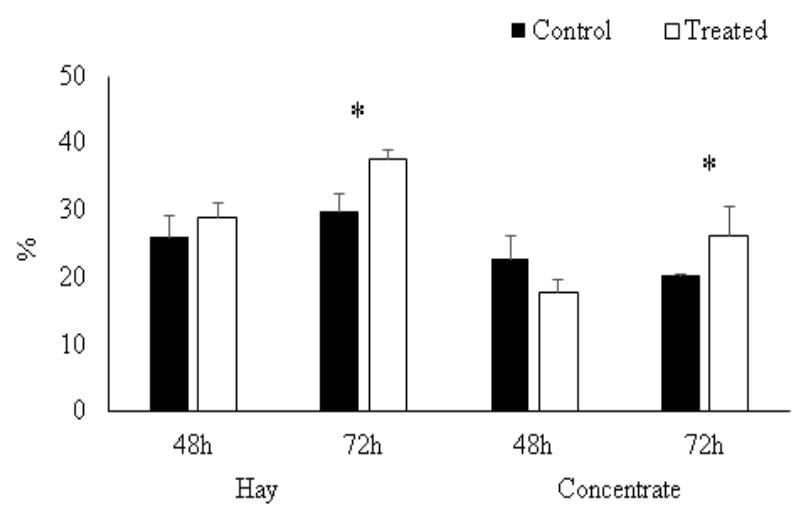

Figure 1. In vitro digestibility using curcumin associated with hay and with concentrate supplied to calves during the experiments at 48 and $72 \mathrm{~h}(* \mathrm{p}<0.05)$.

\section{Discussion}

When analyzing calf weight gain, curcumin increased the average weight gain in 4.4, 8.65 and $10.35 \mathrm{~kg}$ over those of the control group in Experiments 1, 2, and 3, respectively. This result may be due to curcumin potentiating the digestibility of the diet (Rahmani et al., 2017), as verified by the in vitro digestibility test. Consequently, the absorption of nutrients that favor weight gain improved indirectly, that is, the coccidiostatic response to curcumin could have reduced the number of intestinal lesions caused by coccidiosis. The antimicrobial activity of curcumin is already known (Gunes et al., 2013), and feeding curcumin changes the ruminal flora and nitrogen metabolism in beef cattle (Vorlaphim et al., 2011) leading to ruminal fermentation modulation, consequently increasing weight gain.

Curcumin has been shown to reduce the damage caused by coccidiosis in chickens (Kim et al., 2013; Pelícia et al., 2015; Peek et al., 2013). In our study, calves receiving $200 \mathrm{mg}$ curcumin /animal/day had a reduction in oocyst excretion similar to that observed in lambs receiving oral doses of $C$. longa (Cervantes-Valencia et al., 2016). This coccidiostatic property is due 
to induction of cellular apoptosis caused by precipitation in the sporozoite, consequently affecting viability, adhesion capacity and morphology of oocysts (Khalafalla et al., 2011).

In the three experiments, we did not observe an effect of curcumin on the number of red cells, hemoglobin concentration and hematocrit, similar to results in sheep supplemented with curcumin in diet (Jaguezeski et al., 2018). However, in E3, we observed a decreased in the number of leukocytes as a consequence of lower lymphocytes in calves that consumed curcumin in the concentrate; this was not observed in the animals that ingested curcumin in milk. However, the statistical analysis over time showed that curcumin supplementation did not reduce the number of these cells, but it prevented them from the increase observed in the control animals. The discrepancy of leukogram results between experiments may be related to several factors such as age, developing immunity, ruminal morphometry, and form of curcumin intake (in concentrate or milk). It is important to emphasize that calves were fed with a bottle (animals of E1 and E2), so there was a formation of esophageal gutter and therefore milk with curcumin did not pass through the rumen, as opposed to the situation with E3 calves, where curcumin was added to the concentrate. Our hypothesis is that, in young animals, the inflammatory response was stronger due to first contact with microorganisms; consequently, the dose of curcumin ingested by calves (E1 and E2) was not sufficient to reduce the number of leukocytes due to the known antiinflammatory action, recently described in dairy sheep (Jaguezeski et al., 2018).

Recent studies (Cervantes-Valencia et al., 2016; Jaguezeski et al., 2018) showed curcumin has anti-inflammatory properties (Fattori et al., 2015; Kim et al., 2013). In E1 of the present study, treated calves in the pre-weaning phase had an activated immune response, meaning there was an increase of globulin levels. This globulin increase may be a beneficial effect of curcumin, because in the first days of life, animals are exposed to various microorganisms.
In E1, the animals showed a strong immune response from colostrum. Colostrum is rich in immunoglobulins (Ig); one of the globulin fractions that was increased in this study. No inhibitory action of curcumin on $\mathrm{Ig}$ is known, suggesting that curcumin stimulated or at least maintained Ig levels in the blood of these calves. The mechanisms of how this occurred will be the focus of a future study from our research group.

In non-nursing calves (E3), the antiinflammatory effect of dietary curcumin was evident due to reduction of lymphocytes and globulins. This anti-inflammatory action is attributed to the ability of curcumin to block nuclear factor kappa $\mathrm{B}(\mathrm{NF}-\mathrm{Kb})$ and to reduce granuloma growth in response to various inflammatory stimuli without causing toxicity to the organism (Araujo and Leon, 2001). In dairy sheep and lambs, the anti-inflammatory response of curcumin in the diet was also confirmed by inhibition of pro-inflammatory cytokines and increase of anti-inflammatory cytokines (Cervantes-Valencia et al., 2016; Jaguezeski et al., 2018).

In weaned calves, the reduction of oxidants and increase in antioxidants was expected, as the antioxidant properties of curcumin are well-known (Rajput et al., 2014). Lambs supplemented with curcumin also had reduced lipid peroxidation and nitrite levels (CervantesValencia et al., 2016). This is also a welldescribed effect in meat and blood of chickens supplemented with curcumin (Zhang et al., 2015b). The interaction of curcumin with enzymes and genes responsible for the oxidative profile lowers lipid peroxidation and free radical levels (Duan et al., 2012). Curcumin can positively interact with antioxidant enzymes that repair and protect injured cells by eliminating and converting free radicals (e.g., hydrogen peroxide, hydroxyl and superoxide radicals) into water and oxygen (Vincent et al., 2007; ElBahr, 2015). In our study, these effects likely contributed to improve calf performance. 
In the present study, the increase of hay and concentrate digestibility in the presence of curcumin was observed in vitro. Curcumin can also alter in vivo digestibility in ruminants. This was shown in dairy sheep receiving 80 $\mathrm{mg} /$ animal/day, resulting in higher digestibility of neutral detergent fiber and consequently increasing milk production (Jaguezeski et al., 2018). Vorlaphim et al. (2011) found that curcumin increased apparent digestibility of detergent fiber in cattle. These digestibility results help to explain the good performance of calves receiving curcumin.

Apparently, the curcumin modulation effect on the immune response depends on the age of the calf. Curcumin prevented and controlled coccidian infection and reduced oxidative stress. The addition of curcumin also contributed to weight gain of calves at various ages, since curcumin enhances feed digestibility. Curcumin did not affect the metabolism of carbohydrates and lipids, protein catabolism, neither did it have hepatotoxic or nephrotoxic effects. According to the doses, curcumin can have beneficial effects on the health and performance of calves. To ensure safety, more studies are required to explore longer experimental periods with different curcumin doses and greater number of animals per group.

\section{Declarations}

\section{Acknowledgments}

We thank the people at Conselho Nacional de Desenvolvimento Cientifico e Tecnológico (CNPq, Brazil), Coordenação de Aperfeiçoamento de Pessoal de Nivel Superior (CAPES, Brazil) and Universidade do Estado de Santa Catarina (UDESC, Brazil) for their technical support.

\section{Funding}

Funding to conduct the study was provided by UDESC and Universidade Federal de Santa Maria (UFSM).

\section{Conflicts of interest}

The authors declare they have no conflicts of interest with regard to the work presented in this report.

\section{Author contributions}

Patricia Glombowsky and Aleksandro S Da Silva participated in all stages of the study, i.e., project design, experiment execution, sample analysis, data analysis, writing and article editing. Andreia Volpato, Gabriela Campigotto, Natan M Soldá and Daiane da $\mathrm{S}$ dos Santos conducted the field experiment and laboratory analyses. Nathieli B Bottari, Maria Rosa C Schetinger and Vera M Morsch were responsible for biochemistry analyses. Fernanda Rigon and Ana Luiza B Schogor were responsible for bromatological analyses and in vitro tests. All authors participated in the writing and/or review of the article.

\section{References}

Alcalde CR, Machado RM, Santos GT, Picolli R, Jobim CC. Digestibilidade in vitro de alimentos cominóculos de líquido de rúmen ou de fezes de bovinos. Acta Scient: Anim Sci 2001; 23:917921. http://dx.doi.org/10.4025/actascianimsci. v23i0.2645.

Ali SF, Lebel CP,Bondy SC. Reactive oxygen species formation as a biomarker of methylmercury andtrimethyltin neurotoxicity. Neurotoxicol 1992; 113:637-648.

Almeida LP, Naghetini CC, Nunan EA, Junqueira RG, Glória MBA. In vitro antimicrobial activity of the ground rhizome, curcuminoid pigments and essential oil of Curcuma longa L. Cien Agrotec 2008; 32:875-881. http://dx.doi. org/10.1590/S1413-70542008000300026.

Araujo CAC, Leon LL. Biological Activities of Curcuma longa L. MemInst Oswaldo Cruz 2001;96: 723-728. http://dx.doi.org/10.1590/ S0074-02762001000500026. 
Bezerra PQM, Matos MFR, Druzian JI, Nunes IL. Estudo prospectivo da Curcuma longa L. com ênfase na aplicação como corantes de alimentos. Caderno de Prospecção 2013; 6:366-378. http:// dx.doi.org/10.9771/S.CPROSP.2013.006.0041.

Butler JA, SicklesSA, Johanns CJ,Rosenbusch RF. Pasteurization of discard mycoplasma mastitic milk used to feed calves: thermal effects on various mycoplasma. J Dairy Sci 2000; 83:2285-2288. http://dx.doi.org/10.3168/ jds.S0022-0302(00)75114-9.

Busquet M, Calsamiglia S, Ferret A. Plant extracts in vitro rumen microbial fermentation. J Dairy Sci 2000; 89:761-771. http://dx.doi. org/10.3168/jds.S0022-0302(06)72137-3.

Cervantes-Valencia ME, Alcalá-Canto Y,Sumano-Lopez H, Ducoing-Watty AM, Gutierrez-Olvera L. Effects of Curcuma longa dietary inclusion against Eimeria spp. in naturally-infected lambs. Small Rum Res2016; 136: 27-35. https://doi.org/10.1016/j. smallrumres.2015.12.035.

Duan W, Yang Y, Yan J, Yu S, Liu J, Zhou J, Zhang J, Jin Z, YiD. The effects of curcumin post treatment against myocardial ischemia and reperfusion by activation of the JAK2/STAT3 signaling pathway. Basic Res Cardiol 2012; 1:207-263. https://doi.org/10.1007/s00395-0120263-7.

El-Bahr SM. Effect of curcumin on hepatic antioxidant enzymes activities and gene expressions in rats intoxicated with aflatoxin B1. Phytoth Res 2015; 140:134-140. http:// dx.doi.org/10.1002/ptr.5239.

Fascina VB, Sartori JR, Gonzales E, Carvalho FB, Souza IMGP, Polycarpo GV, Stradiotti AC, Pelícia VC. Phytogenic additives and organic acids in broiler chicken diets. Rev Bras Zootec 2012; 41:2189-2197. http://dx.doi.org/10.1590/ S1516-35982012001000008.

Fatorri V, Pinho-Ribeiro FA, Borghi SM, AlvesFilho JC, Cunha TM, Cunha FQ, Casagrande R, Verri WA. Curcumin inhibits superoxide anion-induced pain-like behavior and leukocyte recruitment by increasing Nrf2 expression and reducing NF-kb activation. Inflamm Res 2015; 64:993-1003. http://dx.doi.org/10.1007/s00011015-0885-y.

Gunes H, Gulen D, Mutlu R, Gumus A, Tas T, Topkaya AE. Antibacterial effects of curcumin: An in vitro minimum inhibitory concentration study. Toxicol Indust Health 2013; 32:246-250. http://dx.doi.org/10.1177/0748233713498458.

Jaguezeski AM, Perin G, Bottari NB, Wagner R, Fagundes MB, Schetinger MRC, Da Silva AS. Addition of curcumin to the diet of dairy sheep improves health, performance and milk quality. An Feed SciTechnol 2018; 246:144-157. https:// doi.org/10.1016/j.anifeedsci.2018.10.010.

Jentzsch AM, Bachmann H, Furst P, Biesalski HK. Improved analysis of malondialdehyde in human body fluids. Free Rad Biol Med 1996; 20:251-256.

Habig WH, Pabst MJ, Jakoby WB. Glutathione S-transferase. The first enzymatic step in mercapturic acid formation. J Biol Chem 1974; 249:7130-7139.

Khalafalla RE, Müller U, Shahiduzzaman M, Dyachenko V, Desouky AY, Alber G, Daugschies A. Effects of curcumin (diferuloylmethane) on Eimeria tenella sporozoites in vitro. Parasitol 2011; 108:879-886. http://dx.doi.org/10.1007/ s00436-010-2129-y.

Kim DK, Lillehoj HS, Lee SH, Jang SI, Lilleohoj EP, Bravo D. Dietary Curcuma longa enhances resistance against Eimeria maxima and Eimeriatenella infections in chickens. Poult Sci 2013; 2635-2643. http://dx.doi.org/10.3382/ ps.2013-03095.

Larson LL, Owen FG, Albright JL, Appleman RD, Lamb RC, Muller LD. Guidelines Toward More Uniformity in Measuring and Reporting Calf Experimental Data. J Dairy Sci 1977;60:1-6. https://doi.org/10.3168/jds.S00220302(77)83975-1. 
Lopes KS, Yokobatake LA, Andreotti M, Ferreira JP, Costa NR, Lopes KSM, Carvalho SA. Métodos alternativos para determinação da digestibilidade in vitro da matéria seca em silagem de milho consorciado com gramíneas. Rev Tecnol Ciênc Agrop 2014; 8:73-76. http:// dx.doi.org/10.4025/actascianimsci.v22i0.3187.

Maia NB, Bovi AO, Duarte FR, Soria LG, Almeida JAR. Influência de tipos de rizomas de multiplicação no crescimento de Curcuma longa L. (Cúrcuma). Bragantia 1995; 54:33-37. $\quad$ http://dx.doi.org/10.1590/S0006$\underline{87051995000100004}$.

Mc Cord JM, Fridovich I. Superoxidedismultase. Anenzymicfunction for erythrocuprein (hemocuprein). J Biol Chem1969; 244:60496055.

Molosse V, Souza CF, Baldissera MD, Glombowsky P, Campigotto G, Cazaratto CJ, Stefani LM, Da SilvaAS. Diet supplemented with curcumin for nursing lambs improves animal growth, energetic metabolism, and performance of the antioxidant and immune systems. Small Rum Res 2019; 170:74-81. https://doi. org/10.1016/j.smallrumres.2018.11.014.

Monteiro SC, Parasitologia na medicina veterinária. São Paulo: Rocca, 2010; 356p.

Mota RA, Silva KPC, Ribeiro TCF, Ramos GAB, Lima ET, Silva LBG, Zugica CEA. Eficiência do Nuflor no tratamento de diarreias em bezerros e leitões. Hora Vet 2000; 118: 21-24. http://dx.doi. org/10.1590/S0100-736X2007001000006.

Nelson DP, Kiesow LA. Enthalpy of decomposition of hydrogen peroxide by catalase at $25 \mathrm{c}$ (with molar extinction coefficients of $\mathrm{H} 2 \mathrm{O} 2$ solutions in the UV). Anal Biochem1972; 49:474-478. $\quad$ https://doi.org/10.1016/00032697(72)90451-4

Obaidat MM, Salman AEB, Roess AA. High prevalence and antimicrobial resistance of mecAStaphylococcus aureus in dairy cattle, sheep, and goat bulk tank milk in Jordan. Trop Anim Health Product 2018; 50:405-412. http:// dx.doi.org/10.1007/s11250-017-1449-7.
Peek HW, Halkes SB, Mes JJ, Landman WJ. In vivo screening of four phytochemicals/extracts and a fungal immunomodulatory protein against an Eimeria acervulina infection in broilers. Vet Quart 2013; 33:132-138. http://dx.doi.org/10.1 $\underline{080 / 01652176.2013 .844378}$.

Pelícia VC, Ducatti C,Araujo PC, Stradiotti AC, Aoyagi MM, Fernandes BS, Silva ET, Sartori JR. Ação trófica de aditivos fitogênicos, glutamina e ácido glutâmico sobre a Bursa de Fabrícius e intestino delgado de frango de corte. Pesq Vet Bras 2015; 5:691-699. http://dx.doi. org/10.1590/S0100-736X2015000700015.

Rahmani M, Golian A, Kermanshahi H, Reza Bassami M. Effects of curcumin or nanocurcumin on blood biochemical parameters, intestinal morphology and microbial population of broiler chickens reared under normal and cold stress conditions. J Appl Anim Res 2017; 9: $1-10$. $\quad$ http://dx.doi.org/10.1080/182805 1X.2017.1290510.

Rajput N, Ali S, Naeem M, Khan M.A, Wang $\mathrm{T}$. The effects of dietary supplementation with the natural carotenoids curcumin and lutein on pigmentation, oxidative stability and quality of meat from broiler chickens affected by a coccidiosis challenge. Poult Sci 2014; 1-9. http://dx.doi.org/10.1080/00071668.2014.9255 37

Reis GL, Alburquerque FHMAR, Valente BD, Martins GA, Teodoro RL, Ferreira MBD, Monteiro JBN, Silva MA, Madalena FE. Predição do peso vivo a partir de medidas corporais em animais mestiços Holandês/Gir. Ciênc Rural 2008; 38:778-783. http://dx.doi. org/10.1590/S0103-84782008000300029.

Santos GT, Massuda EM, Kazama DCS, Jobim CC, Branco AF. Bovinocultura Leiteira: Bases zootécnicas, fisiológicas e de produção. Eduem, Maringá 2010.

Silva DJ, Queiroz AC . Análise de alimentos: métodos químicos e biológicos. Editora UFV. Viçosa. 2006; 3.ed. 235p. 
Van Soest PJ. Nutritional ecology of the ruminant. 2.ed. New York: Cornel University Press 1994.

Vincent HK, Innes KE, Vincent KR. Oxidative stress and potential interventions to reduce oxidative stress in overweight and obesity. Diab Obes Metabol 2007; 9:813-39. http://dx.doi. org/10.1111/j.1463-1326.2007.00692.x.

Vorlaphim T, Phonvisay M, Khotsakdee J, Vasupen K, Bureenok S, Wongsuthavas S, Alhaidary A, Mohamed HE, Beynen AC, Yuangklang $\mathrm{C}$. Influence of dietary curcumin on rumen fermentation, macronutrient digestion and nitrogen balance in beef cattle. Am J Agr Biol Sci 2011; 6:7-11. http://dx.doi.org/10.3844/ ajabssp.2011.7.11.
Zhang JF, Hu ZP, Lu CH, Yang MX, Zhang LL, Wang T. Dietary curcumina supplementation protects against heat-stress-impaired growth performance of broilers possibly through a mitochondrial pathway. J Anim Sci 2015a; 93:1656-1665. http://dx.doi.org/10.2527/ jas.2014-8244.

Zhang JF, Hu ZP, Lu CH, Yang MX, Zhang LL, Wang T. Effect of various levels of dietary curcumin on meat quality and antioxidant profile of breast muscle in broilers. J Agric Food Chem 2015b; 63:3880-3886. http://dx.doi. org/10.1021/jf505889b. 